\title{
PENGKAYAAN STOK TERIPANG PASIR (Holothuria scabra) DI PERAIRAN KEPULAUAN SERIBU
}

\author{
Sri Turni Hartati ${ }^{11}$ \\ 1)Peneliti pada Balai Riset Perikanan Laut, Muara Baru-Jakarta \\ Teregristrasi I tanggal: 25 Juli 2007; Diterima setelah perbaikan tanggal: 26 Pebruari 2008; Disetujui terbit tanggal: 4 April 2008
}

\begin{abstract}
ABSTRAK
Akibat aktivitas penangkapan yang berlebihan, stok sumber daya teripang di perairan Kepulauan Seribu, terutama jenis yang bernilai ekonomis tinggi, seperti teripang pasir (Holothuria scabra) sudah mulai langka. Pengkayaan stok adalah salah satu upaya untuk memperoleh sumber daya yang berkesinambungan. Pengkayaan stok teripang pasir telah dilakukan di Kepulauan Seribu melalui 2 tahapan, yaitu pembesaran benih (intermediate culture) yang dilakukan di perairan Pulau Kongsi dan pelepasan di alam (restocking) yang dilakukan di perairan Pulau Pamegaran. Benih yang digunakan berasal dari alam (Teluk Lampung) dan dari panti pembenihan (hatchery). Hasil pengamatan lingkungan menunjukkan bahwa habitat dari ke-2 perairan tersebut mendukung untuk kehidupan teripang pasir. Pertumbuhan teripang baik pada tahap pembesaran benih maupun pelepasan di alam sangat signifikan. Pertumbuhan benih teripang pada 2 bulan pertama dari rata-rata $51 \mathrm{~g}$ menjadi $130 \mathrm{~g}$ per ekor. Pertumbuhan teripang setelah di lepas di alam pada 2 bulan pertama, dari rata-rata $338,50 \mathrm{~g}$ menjadi $619,80 \mathrm{~g}$ per ekor, dan berhasil tertangkap kembali $13 \%$.
\end{abstract}

\section{KATAKUNCI: stok, tripang pasir, Kepulauan Seribu}

\section{PENDAHULUAN}

Sumber daya perikanan adalah merupakan hak milik bersama (common property), sehingga pengelolaan bersifat open access yang berarti siapa saja boleh keluar masuk untuk mengelola (Smith \& Marahudin (Eds), 1985). Oleh karena itu, sering terjadi tekanan sumber daya yang menyebabkan gejala lebih tangkap (over fishing).

Usaha perikanan teripang di Kepulauan Seribu telah dimulai sejak tahun 1973. Tingkat pengusahaan sangat intensif, hasil tangkapan nelayan dapat mencapai 1.000 ekor dalam 1 hari (Azkab \& Hutomo, 1986). Akibatnya, populasi saat ini semakin menurun, bahkan untuk beberapa jenis yang bernilai ekonomis penting cenderung langka, seperti teripang pasir (Holothuria scabra) dan teripang nanas (Thelenota ananas). Menurut Teswara (1995) kepadatan teripang di perairan Kepulauan Seribu berkisar antara 0,147 sampai dengan 0,341 ind. $\mathrm{m}^{-2}$. Penelitian yang dilakukan 5 tahun berikut oleh Hartati et a.l (2002) kepadatan teripang semakin menurun, yaitu hanya berkisar antara 0,016 sampai dengan 0,189 ind. $\mathrm{m}^{-2}$.

Ada beberapa opsi pengelolaan sumber daya ikan yang berkesinambungan, salah satu antara lain pengkayaan stok (stock enhancement). Pengkayaan stok secara umum dapat didefinisikan sebagai suatu usaha meningkatkan ketersediaan sumber daya dengan cara melepas bibit atau benih ikan atau biota lain pada suatu wilayah tertentu yang dianggap sesuai dengan kondisi habitat secara alami dari benih tersebut. Pengkayaan stok beberapa jenis biota mulai diperkenalkan di Jepang pada tahun 1960, karena pada saat itu telah terjadi over fishing yang cukup parah, polusi, dan reklamasi pantai yang sangat pesat. Program yang dijalankan adalah pembesaran bibit (intermediate culture) dan penebaran (restocking). Program pengkayaan stok ini terkenal dengan nama Saibai gyogyo (Kotuki, 1992).

Tulisan ini menyajikan kegiatan pengkayaan stok teripang pasir (Holothuria scabra) di perairan Kepulauan Seribu dalam upaya meningkatkan dan melestarikan stok teripang tersebut yang sudah mulai langka.

\section{PERSYARATAN TEKNIS}

1. Kesesuaian lingkungan dan habitat (suhu, salinitas, kondisi substrat, kepadatan plankton, lamun, dan terumbu karang).

2. Besar benih yang ditebar, yang berhubungan dengan survival rate dan carying capacity yang diharapkan.

3. Mengurangi atau membasmi hama dan predator.

4. Ketersediaan benih, yang dapat diperoleh dari panti pembenihan (hatchery) atau dengan cara memindahkan individu dari suatu tempat ke tempat lain (transplantasi).

5. Partisipasi aktif nelayan dalam pengelolaan dan pengawasan. 


\section{PEMILIHAN LOKASI}

Untuk menentukan lokasi pembesaran benih (intermediate culture) dan penebaran (restocking) di alam dilakukan pengamatan kondisi lingkungan pada beberapa wilayah perairan Kepulauan Seribu, yaitu Pulau Panjang Kecil, Pulau Pamegaran, Pulau Kongsi, dan Pulau Kayu Angin Bira. Hasil pengamatan kondisi lingkungan perairan disajikan pada Tabel 1.

Tabel 1. Kondisi lingkungan pada beberapa wilayah perairan di Kepulauan Seribu

\begin{tabular}{|c|c|c|c|c|c|c|c|c|}
\hline \multirow{2}{*}{ No. } & \multirow{2}{*}{ Parameter } & \multicolumn{7}{|c|}{ Stasiun } \\
\hline & & 1 & 2 & 3 & 4 & 5 & 6 & 7 \\
\hline 1. & Kedalaman (m) & 19,5 & $4,8-6,4$ & $0,57-0,90$ & $2,1-7,37$ & 1 & 13,97 & 4,82 \\
\hline \multirow{2}{*}{$\begin{array}{l}2 . \\
3 .\end{array}$} & \multirow{2}{*}{$\begin{array}{l}\text { Kecerahan }(\%) \\
\text { Salinitas }(\%)\end{array}$} & 71,79 & 100 & 100 & 60 & 100 & 60,84 & 100 \\
\hline & & 32 & $32-33$ & $31,50-32,50$ & $32,00-32,80$ & 32,70 & 32 & 32 \\
\hline 4. & Suhu $\left({ }^{\circ} \mathrm{C}\right)$ & 30,50 & $30,09-30,48$ & $31,1-31,82$ & $30,55-31,15$ & 31,60 & 30,41 & 30,40 \\
\hline 5. & Arus (mis) & 0,14 & $0,03-0,08$ & 0,4 & $0,01-0,05$ & Ttd & 0,16 & 0,06 \\
\hline 6. & $\mathrm{pH}$ & 7,41 & $7,25-7,44$ & $7,50-7,79$ & $7,60-7,93$ & 7,02 & 7,51 & 7,42 \\
\hline 7. & $\begin{array}{l}\text { Fitoplankton } \\
\text { (sel } \mathrm{m}^{3} \text { ) }\end{array}$ & $10^{5}$ & $10^{5}$ & $10^{4}$ & $10^{6}$ & $10^{3}-10^{4}$ & $10^{4}$ & $10^{4}$ \\
\hline & $\begin{array}{l}\text { Zooplankton } \\
\text { (ind. } \mathrm{m}^{-3} \text { ) }\end{array}$ & $10^{3}$ & $10^{4}$ & $10^{4}$ & $10^{4}$ & $10^{3}-10^{4}$ & $10^{3}$ & $10^{3}$ \\
\hline 9. & Substrat & \multicolumn{7}{|c|}{ (Lihat Tabel 2) } \\
\hline 10. & Biologi & $\begin{array}{c}\text { Kr, Pre } \\
\text { Kom,Lm }\end{array}$ & $\begin{array}{l}\text { Kr, Pre } \\
\text { Kom,Lm }\end{array}$ & $\begin{array}{l}\text { Kr, Pre } \\
\text { Kom,Lm }\end{array}$ & $\mathrm{Kr}, \mathrm{Lm}$ & $\mathrm{Kr}, \mathrm{Lm}$ & $\begin{array}{l}\mathrm{Kr}, \text { Pre } \\
\text { Kom,Lm }\end{array}$ & $\begin{array}{l}\text { Kr, Pre } \\
\text { Kom,Lm }\end{array}$ \\
\hline & $\begin{array}{ll}\text { gan: } & \text { 1. stasiun } \\
& \text { Kecil } 2(05 \\
& \text { stasiun } 4 p \\
& \text { S; } 106^{\circ} 35^{\prime} \\
& \text { Angin }\end{array}$ & $\begin{array}{l}\text { rairan Pula } \\
\text { 31,1" S; } 106 \\
\text { an Pulau Pa } \\
\text { " E); } 6 \text {. stas }\end{array}$ & $\begin{array}{l}\text { anjang Kecil } \\
\text { garan } 2 \text { ( } 05^{\circ} 3 \\
6 \text { Pulau Kay }\end{array}$ & $\begin{array}{l}1\left(05^{\circ} 38^{\prime} 31,1^{\prime \prime}\right. \\
\text { stasiun } 3 \text { peraira } \\
38^{\prime} 02,4^{\prime \prime} \text { S; } 106^{\circ} \\
\text { u Angin Bira } 1\end{array}$ & $\begin{array}{l}\text { S; } 106^{\circ} 33^{\prime} 13 \\
\text { an Pulau Pam } \\
\left.34^{\prime} 41,3^{\prime \prime} E\right) ; 5 \text {. } \\
\left(05^{\circ} 36^{\prime} 26,9^{\prime \prime}\right.\end{array}$ & $\begin{array}{l}\text { E); } 2 . \\
\text { aran } 1 \\
\text { siun } 5 \\
06^{\circ} 33\end{array}$ & $\begin{array}{l}\text { In } 2 \text { perairal } \\
\text { '01,7" S; } 10 \\
\text { an Pulau Ko } \\
\text { E); 7. stasi }\end{array}$ & $\begin{array}{l}\text { ulau Panjang } \\
\left.34^{\prime} 18,5^{\prime \prime} E\right) ; 4 . \\
\text { i }\left(05^{\circ} 51^{\prime} 20,6^{\prime \prime}\right. \\
7 \text { Pulau Kayu } \\
\text { mun }\end{array}$ \\
\hline
\end{tabular}

Stasiun 5 yang terletak di sebelah barat Pulau Kongsi ditentukan sebagai lokasi untuk pembesaran benih (intermediate culture), di mana kondisi lingkungan perairan memenuhi persyaratan untuk kehidupan teripang pasir dan pertimbangan kemudahan dalam pengawasan. Pada waktu surut terendah kedalaman perairan lebih dari $30 \mathrm{~cm}$, sesuai persyaratan sebagai lokasi pembesaran teripang, dengan tingkat kecerahan mencapai dasar perairan. Kehadiran lamun sebagai tempat berlindung teripang dan perangkap makanan cukup melimpah. Kecepatan arus pada waktu pengamatan tidak terdeteksi, namun demikian terlihat bahwa pertukaran air di stasiun 5 cukup bagus. Stasiun 4 yang terletak di sebelah utara
Pulau Pamegaran relatif lebih tepat untuk lokasi penebaran di alam (restocking), di mana memiliki lingkungan perairan yang sesuai dengan persyaratan habitat teripang pasir. Substrat dasar perairan relatif lebih halus (Tabel 2), sehingga ada kecenderungan kelimpahan detritus yang merupakan makanan utama teripang selain plankton relatif lebih tinggi. Demikian juga, dengan predator dan kompetitor seperti penyu, ikan-ikan besar, kepiting, bulu babi, bintang laut, dan triton (Martoyo et al., 1994 ) relatif lebih sedikit ditemukan. Secara geografis, wilayah perairan di sekitar Pulau Pamegaran lebih terlindung, semi tertutup dan banyak ditumbuhi tanaman bakau (Gambar 1).

Tabel 2. Persentase ukuran butiran substrat dasar perairan Pulau Pamegaran, Pulau kayu Angin Bira, dan Pulau Panjang Kecil

\begin{tabular}{|c|c|c|c|c|c|}
\hline No. & Kriteria substrat & $\begin{array}{c}\text { Diameter } \\
\text { (mm) }\end{array}$ & $\begin{array}{c}\text { Pulau } \\
\text { Pamegaran } \\
\text { (\%) }\end{array}$ & $\begin{array}{c}\text { Pulau Kayu } \\
\text { Angin Bira } \\
\text { (听) }\end{array}$ & $\begin{array}{c}\text { Pulau Panjang } \\
\text { Kecil } \\
\text { (\%) }\end{array}$ \\
\hline 1. & Butiran, pasir sangat kasar & $=0,800$ & 16 & 14 & 45 \\
\hline 2. & Pasir kasar (course sand) & 0,700 & 2 & 3 & 5 \\
\hline 3. & Pasir (medium sand) & 0,500 & 9 & 19 & 17 \\
\hline 4. & Pasir halus (fine sand) & 0,250 & 24 & 53 & 25 \\
\hline 5. & Pasir halus (fine sand) & 0,149 & 21 & 8 & 5 \\
\hline 6. & Pasir sangat halus (very fine sand) & 0,075 & 11 & 0 & 1 \\
\hline 7. & Lanau kasar (Coorse siit) & 0,053 & 2 & 0 & 0 \\
\hline 8. & Lanau dan lempung & $\leq 0,053$ & 15 & 3 & 2 \\
\hline \multicolumn{3}{|c|}{ Total } & 100 & 100 & 100 \\
\hline
\end{tabular}




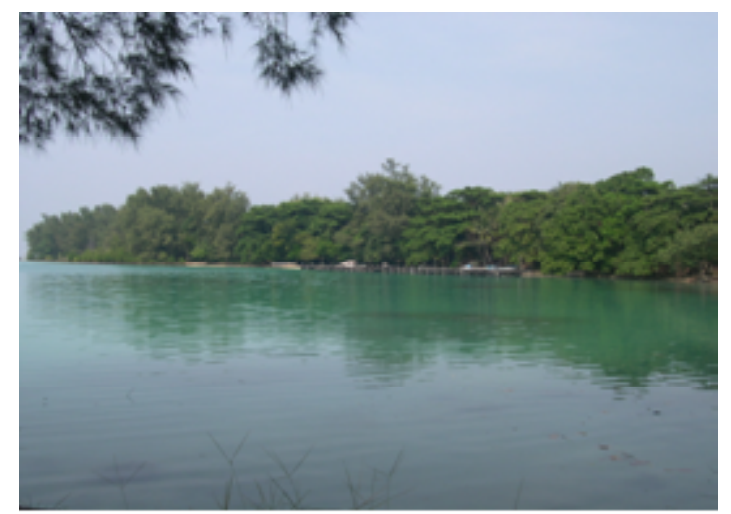

Gambar 1. Perairan utara Pulau Pamegaran sebagai lokasi untuk kegiatan restocking.

\section{SARANA PEMBESARAN BENIH (INTERMEDIATE CULTURE)}

Teripang merupakan hewan yang hidup di dasar perairan dan gerakan relatif lambat. Meskipun gerakan teripang tergolong lambat, desain, dan konstruksi kurungan pagar dapat menjamin teripang tidak lolos dari dasar kurungan pagar. Kurungan pagar dari jaring, dengan bagian bawah dibenamkan pada dasar perairan disebut sebagai jaring tancap berlidah, mempunyai tingkat kelolosan rendah, yaitu maksimum 10\% (Martoyo et al., 1994). Kurung-kurung berbentuk empat persegi panjang atau bujur sangkar dengan ukuran $400 \mathrm{~m}^{2}(20 \times 20 \mathrm{~m})$ atau bahkan 800 $\mathrm{m}^{2}(40 \times 20 \mathrm{~m})$.

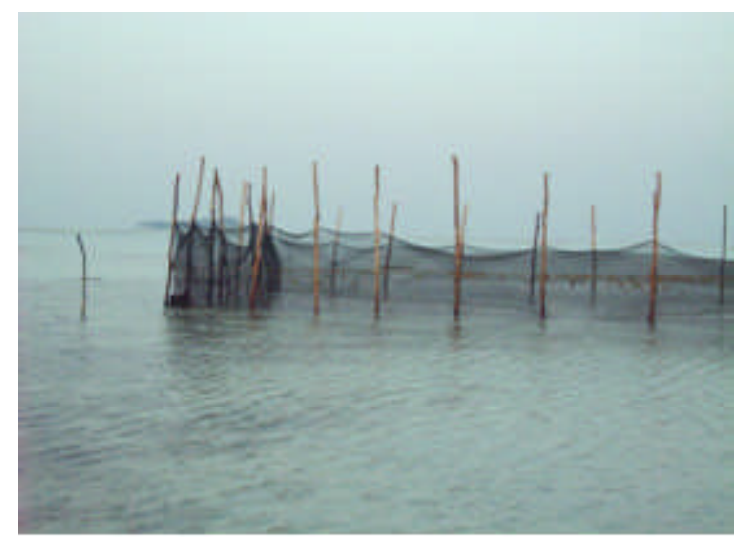

Proses pemasangan jaring tancap berlidah sebagai berikut (Gambar 2):

1. Pancang kayu atau bambu ditancapkan ke dasar perairan sesuai dengan bentuk dan ukuran kurungan pagar yang dikehendaki. Jarak antar pancang berkisar antara 1 sampai dengan $2 \mathrm{~m}$, sedangkan tinggi pancang dari dasar perairan 150 sampai dengan $200 \mathrm{~cm}$.

2. Jaring dari bahan polietilen (PE) dengan lebar mata 0,51 inci direntangkan pada pancang kayu yang telah dipasang di lokasi pembesaran. Bagian jaring yang berada di dasar perairan diikatkan pada sebilah papan dan dibenamkan di dasar perairan agar teripang tidak meloloskan diri.

3. Jaring bagian atas diberi tali ris dari bahan PE yang berdiameter antara 6 sampai dengan $8 \mathrm{~mm}$ agar kuat dan terbuka mata jaring.

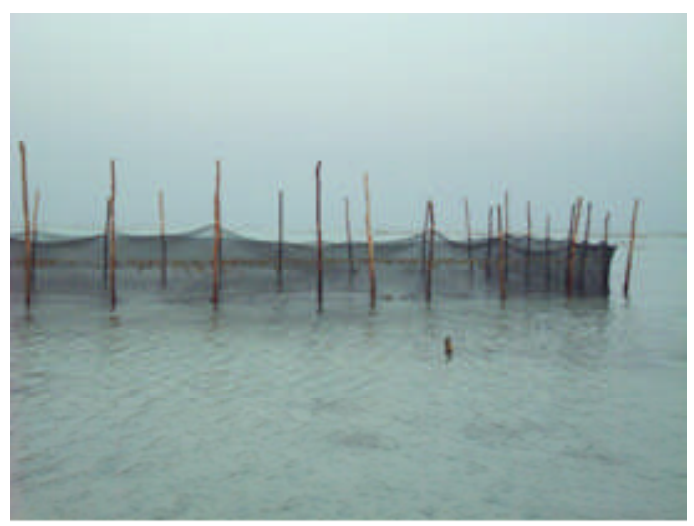

Gambar 2. Kurungan tancap berlidah sebagai sarana intermediate culture di perairan barat Pulau Kongsi.

\section{PENYEDIAAN BENIH}

Benih teripang diperoleh dari 2 sumber, yaitu dari alam dan hasil perbenihan (hatchery). Pada penelitian ini benih alam berasal dari Teluk Lampung dan benih hatchery diperoleh dari Balai Budi Daya Laut Lampung. Untuk pembesaran benih di laut (intermediate culture) diperlukan ukuran panjang benih minimal $10 \mathrm{~cm}$ dengan bobot $20 \mathrm{~g}$ per ekor. Hasil penelitian sebelumnya menunjukkan bahwa ukuran panjang benih kurang dari $10 \mathrm{~cm}$ dan bobot kurang dari $20 \mathrm{~g}$ akan cenderung dimakan predator. Proses pemilihan benih dan penempatan sementara dikurungkurung yang terbuat dari jaring disajikan pada Gambar 3 sampai dengan 5 . 

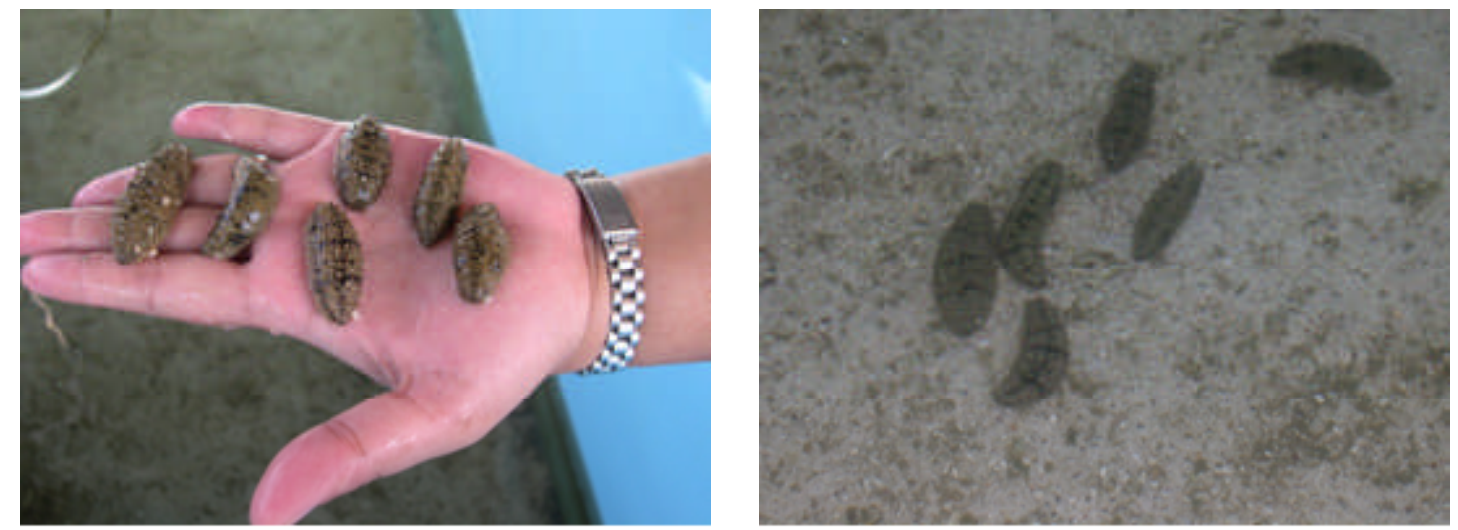

Gambar 3. Perkembangan teripang anakan di hatchery setelah berumur 2 sampai dengan 4 bulan, bobot 2 sampai dengan $5 \mathrm{~g}$ per ekor dan panjang antara 2 sampai dengan $7 \mathrm{~cm}$.
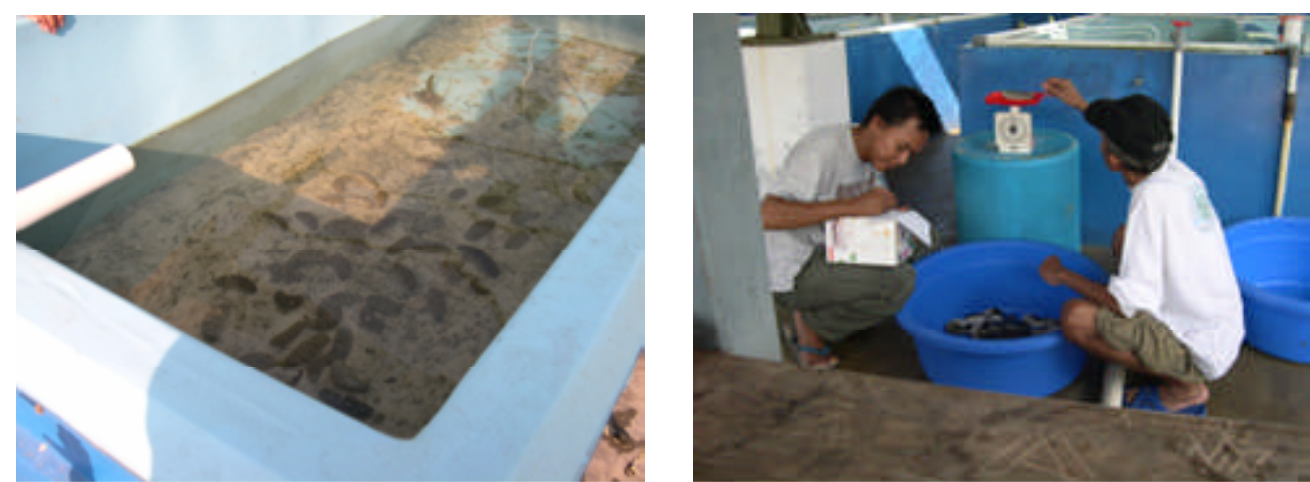

Gambar 4. Teripang anakan dari alam dengan bobot kurang dari $50 \mathrm{~g}$ per ekor dalam bak-bak penampungan.
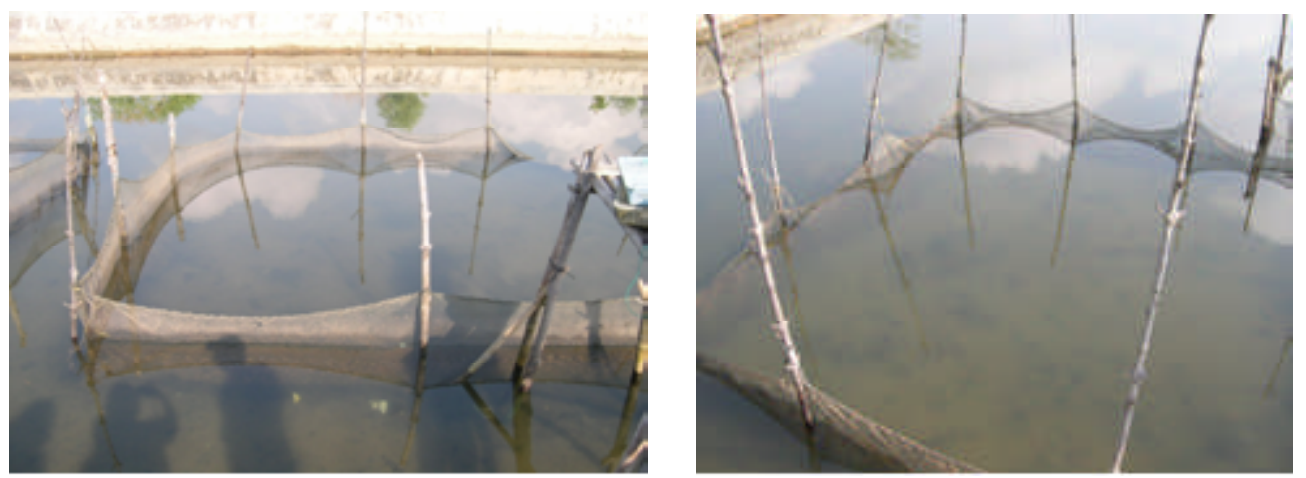

Gambar 5. Teripang anakan dengan bobot lebih dari $50 \mathrm{~g}$ per ekor dalam kurung-kurung jaring di tambak, sebelum dipindahkan ke tempat pembesaran di Kepulauan Seribu.

\section{PENGANGKUTAN BENIH}

Ada 2 kelompok ukuran teripang anakan dari alam yang diperoleh dari Teluk Lampung yaitu berukuran $<100 \mathrm{~g}$ dan $>100 \mathrm{~g}$ per ekor. Sebelum proses pengangkutan benih dikemas dalam kantong plastik yang berisi air dan oksigen dengan perbandingan 1:2. Kemudian kantong dimasukan dalam kotak atau dus steroform dan diberi pendingin berupa es batu yang dibungkus dengan koran. Kemudian benih diangkut lewat darat dan laut (waktu tempuh dari Lampung ke Kepulauan Seribu selama 17 jam), dengan keloloshidupan $100 \%$. Ukuran benih dan proses pengepakan disajikan pada Gambar 6 dan 7 . 

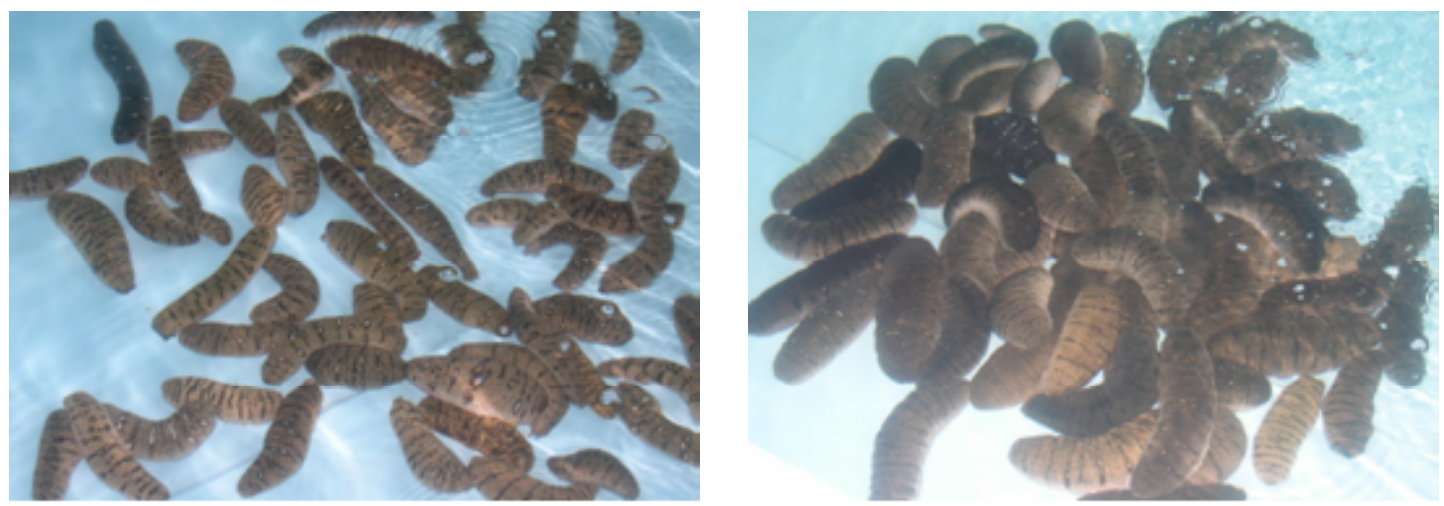

Gambar 6. Benih teripang alam dari Teluk Lampung yang telah dikosongkan isi lambung (diberokan), siap untuk dibawa ke tempat pembesaran di Kepulauan Seribu. Bobot benih pada kisaran $<100$ sampai dengan $>100 \mathrm{~g}$ per ekor.
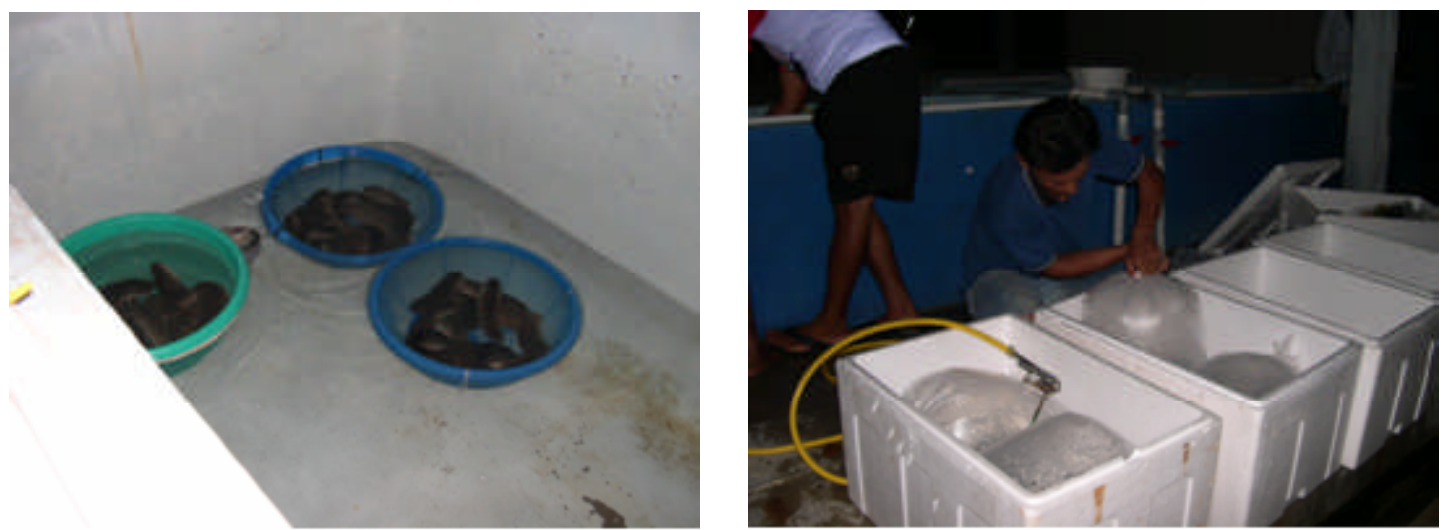

Gambar 7. Proses pengepakan benih teripang.

\section{PEMBESARAN BENIH DAN PELEPASAN DI ALAM}

Benih yang berukuran kecil ( $<100 \mathrm{~g}$ per ekor) dibesarkan dahulu dalam intermediate culture yang

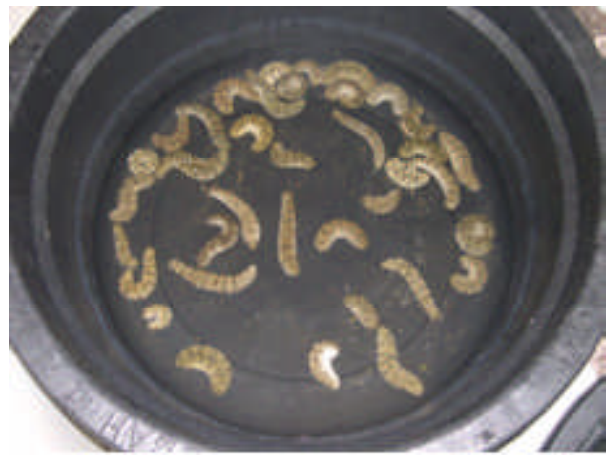

Gambar 8. Proses penimbangan benih yang akan dibesarkan dalam intermediate culture.

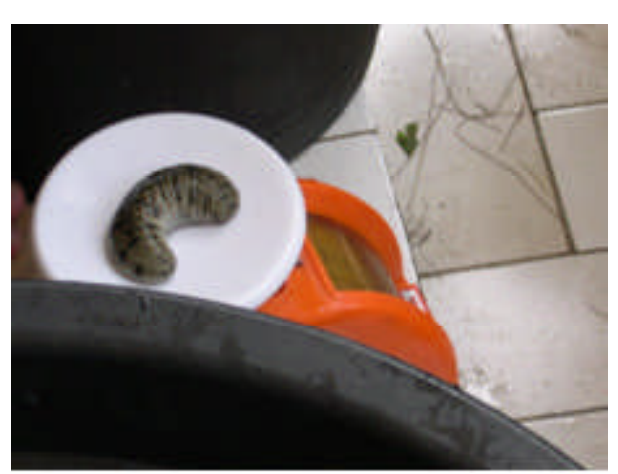

berlokasi di perairan barat Pulau Kongsi, sedangkan benih yang berukuran $>100 \mathrm{~g}$ langsung dilepas (restocking) di perairan utara Pulau Pamegaran. Proses pemilihan ukuran benih dan pelepasan di 

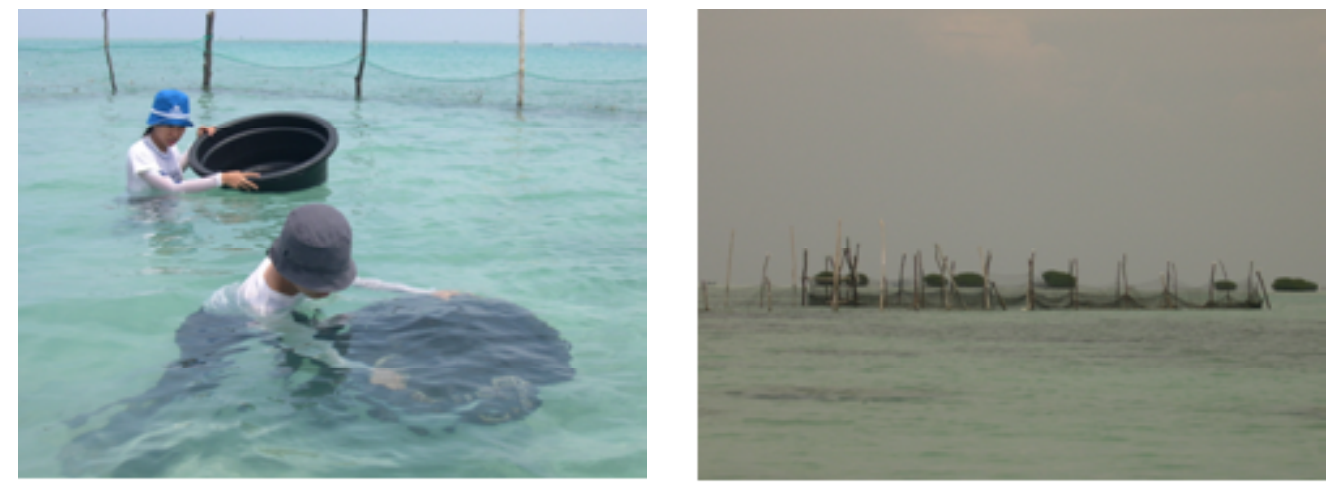

Gambar 9. Pelaksanaan intermediate culture di bagian barat Pulau Kongsi.
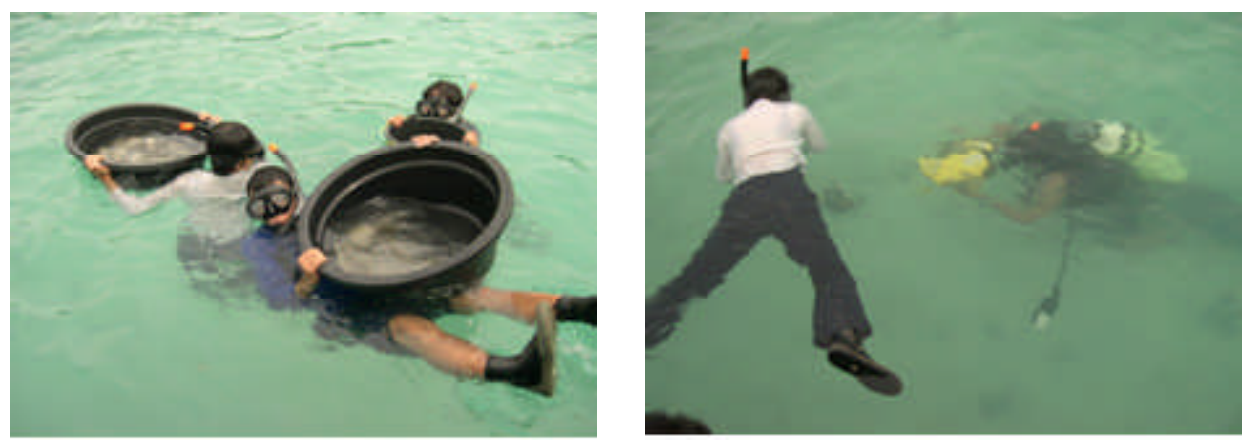

Gambar 10. Pelaksanaan restocking di bagian utara Pulau Pamegaran, Kepulauan Seribu.

tempat pembesaran disajikan pada Gambar 8 sampai dengan 10.

\section{PERKEMBANGAN TERIPANG}

Perkembangan teripang alam yang dipilih dari Teluk Lampung yang telah dibesarkan di intermediate culture dan direstocking (dilepas) disajikan pada Tabel 3 dan 4 . Benih teripang yang akan dibesarkan 400 ekor dengan bobot rata-rata $51 \mathrm{~g}$ per ekor. Pengamatan pada bulan pertama dan ke-2 rata-rata mencapai $119 \mathrm{~g}$ per ekor dan $130 \mathrm{~g}$ per ekor. Pengamatan pada teripang yang dilepas di alam, pada bulan pertama ditemukan kembali 70 ekor atau $17,5 \%$ dari jumlah awal 400 ekor (100\%). Bobot awal rata- rata $338,50 \mathrm{~g}$ per ekor menjadi $468,0 \mathrm{~g}$ per ekor. Pada bulan ke-2 tertangkap kembali 52 ekor (13\%) dengan rata-rata bobot $619,80 \mathrm{~g}$ per ekor.

Pergerakan teripang yang dilepas di alam pada pengamatan bulan pertama mencapai jarak $61 \mathrm{~m}$ dari titik awal, menuju ke perairan yang lebih dalam dengan substrat dasar perairan lebih halus. Pengamatan bulan ke-2 menunjukkan pergerakan teripang mencapai 198 $\mathrm{m}$ ke arah perairan dengan substrat dasar pasir berlumpur. Pengamatan perkembangan pertumbuhan teripang pasir di dasar perairan disajikan pada Gmbar 11. Pengamatan dilakukan dengan cara diselam, diangkat ke darat kemudian ditimbang bobot dan diukur panjang. Teripang yang sudah diamati dikembalikan ke lokasi penangkapan.

Tabel 3. Pemantauan pertumbuhan benih teripang dalam intermediate culture

\begin{tabular}{lccc}
\hline & Awal & Pemantauan bulan ke-1 & Pemantauanbulan ke-2 \\
\hline Total (ekor) & 400 & Contoh 60 ekor & Contoh 60 ekor \\
Rata-rata bobot per ekor $(g)$ & 51 & 119 & 130 \\
\hline
\end{tabular}

Tabel 4. Jumlah (ekor) dan rata-rata bobot (g) teripang yang dilepas (restocking) serta hasil pemantauan pada bulan ke-1 dan 2 pasca pelepasan

\begin{tabular}{lccc}
\hline & Pelepasan & Pemantauan bulan ke-1 & Pemantauan bulan ke-2 \\
\hline Total (ekor) & $400(100 \%)$ & $70(17,5 \%)$ & $52(13 \%)$ \\
Rata-rata bobot $(\mathrm{g})$ & 338,50 & 468,0 & 619,80 \\
Pergerakan $(\mathrm{m})$ & Awal $(0)$ & 61 & 198 \\
\hline
\end{tabular}



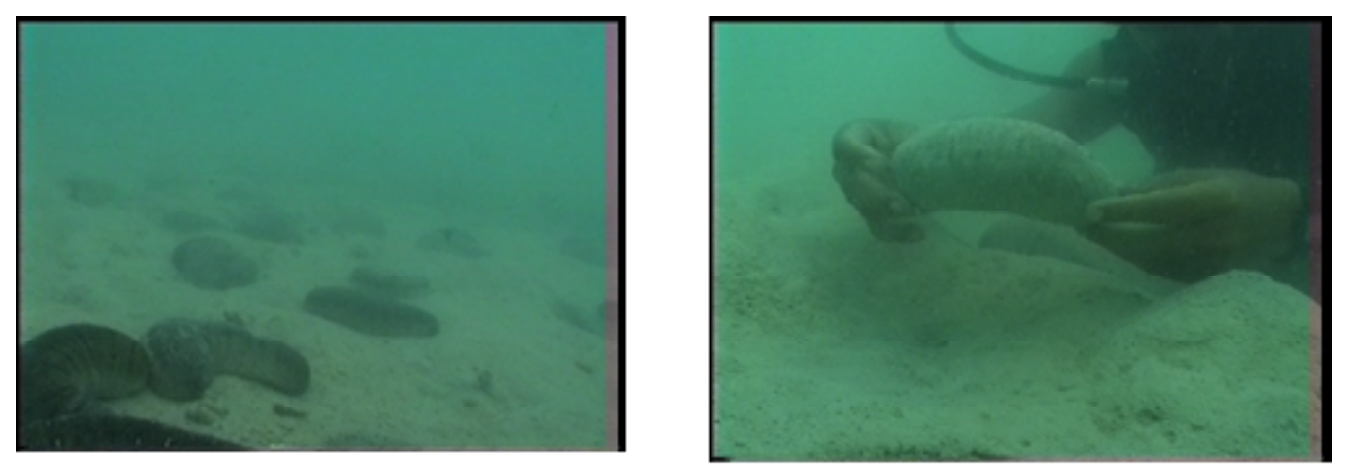

Gambar 11. Pengamatan stok teripang di dasar perairan pasca pelepasan di alam (restocking).

\section{KESIMPULAN}

1. Kondisi lingkungan perairan Pulau Kongsi dan Pulau Pamegaran mendukung untuk pertumbuhan teripang pasir.

2. Pertumbuhan teripang pasir baik pada tahap pembesaran benih maupun pelepasan di alam menunjukkan perkembangan yang signifikan.

3. Pemulihan populasi teripang pasir (Holothuria scabra) yang sudah mulai langka di Kepulauan Seribu, dapat dilakukan melalui penebaran dalam volume yang lebih besar pada beberapa lokasi yang mempunyai kesesuaian habitat.

\section{PERSANTUNAN}

Kegiatan dari hasil riset pemacuan stok teripang di perairan Kepulauan Seribu, T.A. 2004, di Pusat Riset Perikanan Tangkap, Ancol-Jakarta.

\section{DAFTAR PUSTAKA}

Azkab, H. M. \& M. Hutomo. 1986. Sumber daya Kepulauan Seribu dan peranan stasiun penelitian oseanoogi Pulau Pari. Oseana. Vol.XI No.2. Hal. 45.

Hartati, S. T., S. Wahyuni, \& R. Zainy. 2002. Beberapa aspek biologi teripang di perairan Kepulauan Seribu. Jurnal Penelitian Perikanan Indonesia. Vol.8 No.1 Tahun 2002. Pusat Riset Perikanan Tangkap. Badan Riset_Kelautan dan Perikanan. Departemen Kelautan dan Perikanan. Jakarta.

Kotuki, K. 1992. The state and prospecs_of stock enhancement (Saibai Gyogyo) Project in Japan. FAO Fisheries Report No.974. SUPPL. Vol.1. 197204.

Martoyo, J., N. Aji, \& T. Winarto. 1994. Budi daya teripang. Penebar Swadaya. Jakarta.

Smith, I. R. \& F. Marahudin. 1985 (Eds). Ekonomi perikanan; Dari teori ekonomi pengelolaan perikanan. Yayasan Obor Indonesia Gramedia. Jakarta.

Teswara, A. 1995. Perbandingan komposisi jenis-jenis teripang (Holothuroidea) di Pulau Kayu Angin Bira dan Pulau Pramuka. Taman Nasional Laut Pulau Seribu. Jakarta. Universitas Nasional. Jakarta. 